\title{
"PoZdro!" as an example of a successful multicenter programme for obesity management and healthy lifestyle promotion in children and adolescents - programme protocol and preliminary results from the first intervention site
} „PoZdro!" jako przykład skutecznego wieloośrodkowego programu zwalczania otyłości i promowania zdrowego stylu życia u dzieci i młodzieży w Polsce - protokół badania oraz doniesienia wstępne z pierwszego ośrodka

1,2Michał Brzeziński, ${ }^{1,3}$ Katarzyna Korzeniowska, ${ }^{1}$ Kamila Szarejko, ${ }^{1}$ Marcin Radziwił, 1,3 Malgorzata Myśliwiec, 1,4Tomasz Anyszek, 1,5 Leszek Czupryniak, 1,6Per-Olof Berggren, ${ }^{1}$ Piotr Soszyński

1"PoZdro!" Programme Scientific Board, Medicover Foundation, Poland ${ }^{2}$ Department of Paediatrics, Gastroenterology, Allergology and Paediatric Nutrition, Medical University of Gdansk, Poland

${ }^{3}$ Department of Paediatrics, Diabetology and Endocrinology, Medical University of Gdansk, Poland ${ }^{4}$ Synevo sp. z o.o., Poland

${ }^{5}$ Department of Diabetology and Internal Diseases, Warsaw Medical University, Poland

${ }^{6}$ The Rolf Luft Research Center for Diabetes and Endocrinology, Karolinska Institutet, Sweden

\begin{abstract}
Introduction: Overweight and obesity rates in children and adolescents increase worldwide for over 30 years, what leads to an increased risk of developing metabolic diseases.

Aim of the study: Protocol description and preliminary results of the largest to-date obesity management programme for children in Poland - "PoZdro!"

Material and methods: The Programme is based on three main steps: screening, parental engagement and long-term behavioral intervention (medical, dietetic, psychological, physical activity intervention panels) and education activities in secondary schools. Over 30.000 children were screened in four big Polish cities and over 2.000 engaged in the programme.

Results: Preliminary results from the first city show that, since 2014, 3998 of the 6346 (63\%) eligible students from 24 schools (first grade of the secondary school) were screened. $16 \%$ of the children were overweight (body mass index $-\mathrm{BMI}^{2} 85^{\text {th }}<95^{\text {th }} \mathrm{centile)}$ and $4.7 \%$ were obese $\left(\mathrm{BMI} \geq 95^{\text {th }}\right.$ centile). 603 children fulfilling the qualification (QUA) criteria (BMI > 90th centile) were offered the Individual Integrated Care (IIC). 470 (77.94\% of QUA) began and 253 (41.96\% of QUA, 53.82\% of IIC) finished the full interventional programme with the mean BMI centile decrease of 3.04 in two following years.

Conclusions: "PoZdro!" is a unique obesity prevention and management programme in Poland operating simultaneously in several Polish big cities. The programme incorporates parental engagement and long-term behavioral intervention. Preliminary results show that it may result in meaningful decrease in BMI in two following years. Further data analyses are necessary to show the influence of the programme on metabolic risk in studied group.
\end{abstract}

Key words:

obesity, preventive programmes, child health, community health services.

\section{Streszczenie}

Wprowadzenie: Od ponad 30 lat obserwuje się rosnący trend otyłości wśród dzieci i młodzieży na całym świecie, co skutkuje zwiększeniem ryzyka rozwoju chorób metabolicznych.

Cel: Opis protokołu oraz wstępne wyniki dotychczas największego programu profilaktyki oraz walki z otyłością u dzieci w Polsce „PoZdro!”. Materiał i metody: Program oparty jest na trzech filarach: skriningu, zaangażowaniu opiekunów podczas długotrwałej interwencji behawioralnej (panele lekarza, dietetyka, psychologa, specjalisty aktywności fizycznej) oraz zajęciach edukacyjnych w szkołach 
średnich. Program zapewnia skoordynowaną pomoc dla nastolatków z nadwagą lub otyłością oraz ich rodzin w 4 dużych polskich miastach. W skriningu uczestniczyło ponad 30 000, a w Programie ponad 2000 dzieci.

Wyniki: Wstępne wyniki z Gdyni pokazują, iż od 2014 r. przebadano 3998 spośród 6346 (63\%) kwalifikujących się uczniów z 24 szkół (pierwsza klasa szkoły średniej). U 16\% dzieci stwierdzono nadwagę (wskaźnik masy ciała; body mass index - BMI z 85 . centyla < 95. centyla) a u 4.7\% otyłość (BMI $\geq 95$. centyla). Dzieciom spełniającym kryteria włączenia do programu (603 dzieci z BMI > 90. centyla) zaproponowano udział w zintegrowanej opiece indywidualnej (ZOI). Z tego 470 (77,94\% z zakwalifikowanych) rozpoczęło, a 253 (41,96\% zakwalifikowanych, 53,82\% z ZOI) ukończyło program interwencyjny ze średnim obniżeniem centyla BMI o 3,04 po 2 latach.

Wnioski: „PoZdro!” jest jedynym programem zapobiegania oraz walki z otyłością w Polsce przeprowadzanym jednocześnie w kilku dużych miastach. Program łączy zaangażowanie opiekunów z długotrwałą interwencją behawioralną. Wyniki wstępne pokazują, że skoordynowana, wielodyscyplinarna interwencja może przyczynić się do znacznego zmniejszenia BMI na przestrzeni 2 lat. Dalsze analizy danych pozwolą na ocenę wpływu programu na ryzyko rozwoju chorób metabolicznych w badanej grupie.

\section{Słowa kluczowe:}

otyłość, programy profilaktyczne, zdrowie dziecka, zdrowie społeczne.

\section{Introduction}

Overweight and obesity prevalence in children and adolescents increase in developed and developing countries worldwide for more than 30 years [1].

There are no consistent data about obesity problem among children in Poland. Available national data from 2007-2009 show that the prevalence of overweight and obesity among adolescents aged $13-18$ years was in the range of $14.6-19.4 \%$ and $10.3-13.0 \%$, boys and girls, respectively, using international definitions of childhood overweight [2]. Although obesity rates among children and adults are becoming one of the main public health issues, no effective national policy to tackle this problem has been formulated yet.

This paper describes the concept, protocol and preliminary results of the largest obesity management programme for adolescents in Poland - "PoZdro!" (National Programme for the Prevention of Diabetes and Lifestyle Diseases) - initiated by Medicover Foundation and funded by a grant from the Jochnick Family Foundation.

\section{Material and methods}

The Programme is a multicenter before and after intervention non-controlled study measuring the effectiveness of the integrated behavioral intervention in adolescents on their body mass index and body composition.

"PoZdro!" is based on three main steps: screening, interdisciplinary intervention and education activities in secondary schools. Study structure and patients flow is presented in Figure 1.

\section{Screening - comprehensive health assessment}

The screening is carried out by the specially trained nurses in secondary schools from four cities in Poland - Gdynia, Lublin, Wroclaw and Warsaw.

The main screening procedure and reference points are outlined in Table I. All children taking part in the screening must have provided written parental consent. An additional questionnaire, focused on nutrition-related behaviors and physical activity, was given to all parents participating in the programme.

Educational materials, summary of screening results and clinical recommendations were provided to parents of all children who took part in the screening. If a life-threatening condition or a major health problem was discovered, the child was referred to a pediatric department or a GP.

\section{Intervention - Individual Integrated Care}

All children with BMI above the $90^{\text {th }}$ percentile for age and sex according to actual polish centile charts [3] were invited to take part in a two-year-long intervention programme.

The Individual Integrated Care (IIC) programme consists of eight consultations delivered in outpatient Medicover Centers scheduled in the following intervals: at 0-6 weeks, 3 months, 6 months, 9 months, 12 months, 18 months, and 24 months. During each visit the patient (and their parent/s) undergoes a series of tests and consultations with a physician, dietician, psychologist, and a physical activity specialist.

Additionally, after the first and before the last visit, laboratory tests for biochemical markers of diabetes and cardiovascular risk are carried out as presented below.

Anthropometry: Body weight and height are measured with a digital scale (Mensor WE150, Poland), with the child in the standing position, in underwear and barefoot. Polish centile charts are used to assess BMI [3].

Waist and hip circumference are measured on a horizontal plane using the Ergonomic Circumference Measuring Tape (model 201; Seca GmbH \& Co, KG, Hamburg, Germany). Polish reference values are used to assess abdominal obesity [4].

Blood pressure measurements: Arterial blood pressure is measured on the left arm at the heart level, using an oscilIometric technique (Omron) with adequate cuff size, with the child sitting down, legs uncrossed, and with at least 5 minutes' rest in sitting position before the measurement. Three separate measurements of blood pressure are taken and their average value is recorded [5] 


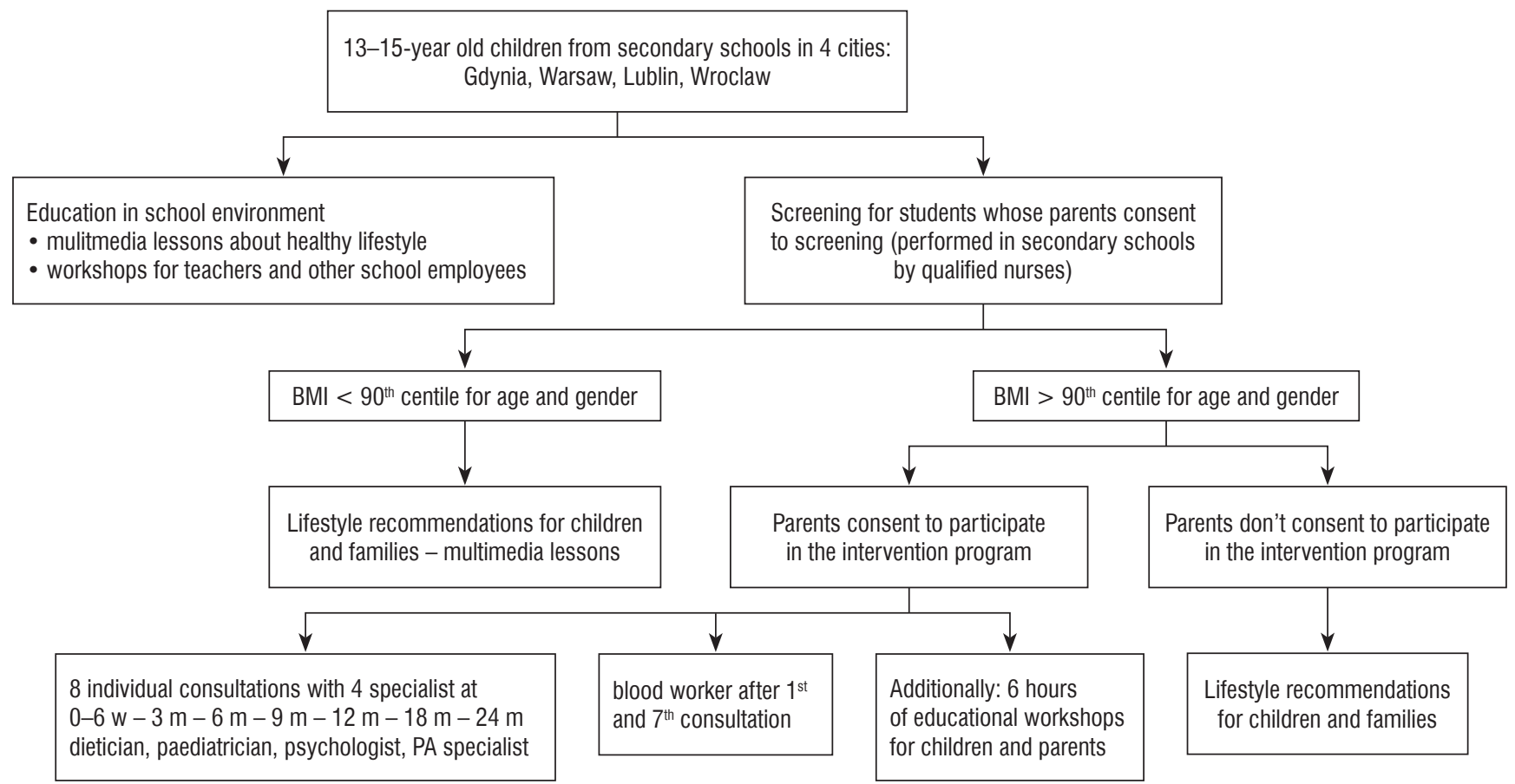

Figure 1. Programme "PoZdro!" structure and patients flow

Diet assessment: Dietary journals covering three consecutive days (2 weekdays +1 day of the weekend) prior to joining the programme and at the end of the programme are analysed - caloric intake and dietary intake of nutrients are calculated with validated Dieta 5.0 software (Institute of Food and Nutrition, Warsaw).

Psychological assessment of readiness to change is based on Prochaska model (validated structured interview) [6] . The aim of psychological consultations is mostly strengthening the motivation of the child and their parents to introduce healthy lifestyle changes.

Consultations with a physical activity specialist aim at assessment of body posture defects, muscular strength development, assessment of cardiorespiratory fitness [7] based on the results defining optimal levels of physical activity, adjusted to child's body mass, abilities and preferences, developing a training programme with gradually increasing intensity.

Biochemical measurements include complete blood count, lipid profile (enzymatic method); oral glucose tolerance test (OGTT) with concentration of glucose (hexokinase method) and insulin (immunochemiluminescence assay); alanine transaminase (ALT), thyroid stimulating hormone (TSH), free thyroxine (fT4).

\section{Educational workshops}

Parents and children are invited to take part in educational workshops run by a dietician, psychologist and workshop on food marketing, labelling and sugar dependence. These 6-hour-long workshops delivered in cities conference centers are developed to enhance motivation, provide knowledge and create a positive attitude towards lifestyle changes.

\section{Results}

Preliminary results from Gdynia

In this paper we present preliminary data from the first city involved in the programme - Gdynia. Full data from all cities and years of programme will be presented after fulfillment of the programme, in 2020. 3998 children (63\% of Gdynia 13-years-old population) were screened during 2013-2017 screening phase. Out of that number 643 children (16.0\%) were overweight and $190(4.7 \%)$ were obese. Overweight and obesity rates were higher in boys $(17.7 \% ; 6.2 \%)$ than in girls $(14.4 \% ; 3.3 \%)$.

Out of the children with overweight and obesity 603 (15,1\%) with BMI above 90th centile were qualified to the interventional part of the programme. Out of 603 qualified children (QUA), 470 (77.94\%) were engaged in IIC. From the 470 engaged in the IIC 253 (41.96\% of QUA; 53.83\% of IIC) finished all 8 visits. The highest dropout rate was observed after the 1st visit (15.74\%).

The analyses showed that children who completed the whole intervention programme had significantly higher decrease in BMI centile, SBP and DBP as well as in total body fat. Details are presented in Table II.

When assessing changes in BMI centile on a literature established success ratio [8] - measured as decrease in BMI 
centile $\geq 5$ there is a significant difference between those two groups: 66 vs. 41 participants (26.19\% vs. 18.98\%, Fisher's exact test $p$ value $=0.0404$ ) fulfilling that criteria. The mean decrease in BMI centile in the group that completed the whole intervention programme was 3.04 , whereas in the lost-to-follow-up or discontinuation group the BMI centile decreased only insignificantly.

\section{Discussion}

"PoZdro!" is the only obesity prevention and management programme in Poland operating simultaneously in four big cities. The programme was designed according to the best available (in 2013) evidence [9] and it includes significant parental engagement and long-term behavioral intervention. The authors of the programme aimed to create an effective intervention in the field of childhood obesity, adapted to the local Polish environment as there are no national programmes of children obesity management including individual health assistance.

Presented results show that the participants who finished the whole two year programme had a significantly higher decreasing rate in BMI. 25\% of participants from Gdynia achieved 5.0 centiles BMl reduction, which is much above the average comparing to previously published data [10]. Moreover, presented data show to-date biggest documented reduction in the percentage of the body fat among the patients who finished the programme.

As previously mentioned, these results only represent data of 603 children (from the first introduced city) out of over 2000 included in the intervention until the end of the year 2019. Further analyses from all four cities are necessary to discuss the effect of the programme on metabolic risk of the studied group.
Table I. Main tests performed during screening in the "PoZdro!" programme

\begin{tabular}{|c|c|c|}
\hline Test & Goal & References \\
\hline Body mass & $\begin{array}{l}\text { Measuring body } \\
\text { mass }\end{array}$ & $\begin{array}{l}\text { Polish Centile Charts } \\
\text { of body mass for sex } \\
\text { and age [3] }\end{array}$ \\
\hline Height & Measuring height & $\begin{array}{l}\text { Polish Centile Charts } \\
\text { of body height for sex } \\
\text { and age [3] }\end{array}$ \\
\hline $\mathrm{BMI}$ & $\begin{array}{l}\text { Determining } \\
\text { presence of } \\
\text { overweight or obesity }\end{array}$ & $\begin{array}{l}\text { Polish Centile Charts of } \\
\text { BMI for sex and age [3] }\end{array}$ \\
\hline $\begin{array}{l}\text { Waist and hip } \\
\text { circumference }\end{array}$ & $\begin{array}{l}\text { Determining } \\
\text { presence of } \\
\text { abdominal obesity }\end{array}$ & $\begin{array}{l}\text { Polish Centile Charts of } \\
\text { waist circumference for } \\
\text { sex and age [4] }\end{array}$ \\
\hline $\begin{array}{l}\text { Blood } \\
\text { pressure }\end{array}$ & $\begin{array}{l}\text { Determining } \\
\text { presence of } \\
\text { hypertension }\end{array}$ & $\begin{array}{l}\text { Polish Centile Charts of } \\
\text { blood pressure for sex } \\
\text { and age [5] }\end{array}$ \\
\hline $\begin{array}{l}\text { Post-exercise } \\
\text { heart rate }\end{array}$ & $\begin{array}{l}\text { Assessing } \\
\text { cardiorespiratory } \\
\text { fitness }\end{array}$ & $\begin{array}{l}\text { Kasch Pulse Recovery } \\
\text { Test reference system [6] }\end{array}$ \\
\hline $\begin{array}{l}\text { Vision } \\
\text { screening }\end{array}$ & $\begin{array}{l}\text { Assessing defects of } \\
\text { vision }\end{array}$ & $\begin{array}{l}\text { Standard Polish vision } \\
\text { screening protocol }\end{array}$ \\
\hline $\begin{array}{l}\text { Body posture } \\
\text { screening }\end{array}$ & $\begin{array}{l}\text { Assessing presence } \\
\text { of postural defects }\end{array}$ & $\begin{array}{l}\text { Visual assessment with } \\
\text { use of podoscope }\end{array}$ \\
\hline
\end{tabular}

Table II. Main tests performed during screening in the "PoZdro!" programme

\begin{tabular}{|c|c|c|c|c|c|c|c|}
\hline \multirow[t]{2}{*}{ Number of visits } & \multicolumn{2}{|c|}{ No. of children } & \multicolumn{2}{|c|}{ Median } & \multicolumn{2}{|l|}{$\mathrm{SD}$} & \multirow[t]{2}{*}{$p$ value* } \\
\hline & $<8$ & 8 & $<8$ & 8 & $<8$ & 8 & \\
\hline$\Delta \mathrm{BMI}$ centile & 216 & 252 & -1.85 & -3.04 & 5.25 & 8.16 & 0.066438 \\
\hline$\Delta$ SBP centile & 217 & 253 & -4.17 & -11.41 & 25.06 & 27.02 & 0.002891 \\
\hline$\Delta$ DBP centile & 217 & 253 & -3.30 & -8.68 & 32.16 & 29.06 & 0.057223 \\
\hline$\Delta$ Body fat $\%$ & 216 & 253 & 0.23 & -1.02 & 4.44 & 4.83 & 0.003760 \\
\hline$\Delta$ Post_ex HR & 97 & 138 & -7.12 & -9.74 & 16.66 & 15.39 & 0.216365 \\
\hline
\end{tabular}

$\Delta$ - change; BMl - body mass index; SBP - systolic blood pressure; DBP - diastolic blood pressure; post ex HR - post exercise heart rate; * t-Student's 
Brzeziński M., Korzeniowska K., Szarejko K., Radziwiłł M., Mysliwiec M., Anyszek T., Czupryniak L., Berggren P.-O., Soszyński P.

\section{Conclusions}

"PoZdro!" programme is the first in Poland multicenter before and after intervention programme build as a response to increasing obesity problem in adolescents. Based on available recommendations and standards, the programme was created as an interdisciplinary, longitudinal activity focused not only on body mass index decrease but change of lifestyle behaviors in adolescents and their families. The preliminary results show that those participants who decided to participate had a visible change in body mass index and body fat percentage through the two year intervention process.

\section{Ethics approval and consent to participate}

All parents of students participating in the screening and in the intervention stage have provided written consent for the screening of their children.

The screening protocol and the intervention protocol have been approved by the Independent Bioethics Commis-

\section{References}

1. Bentham J, Di Cesare M, Bilano V, et al. Worldwide trends in bodymass index, underweight, overweight, and obesity from 1975 to 2016: a pooled analysis of 2416 population-based measurement studies in 128.9 million children, adolescents, and adults. Lancet 2017; 390: 2627-2642. doi: 10.1016/S0140-6736(17)32129-3

2. Brzeziński $M$, Jankowski $M$, Jankowska $A$, et al. Is there a rapid increase in prevalence of obesity in Polish children? An 18-year prospective observational study in Gdansk, Poland. Arch Med Sci 2018; 1: 22-29. doi: 10.5114/aoms.2018.72239

3. Kułaga Z, Litwin M, Tkaczyk M, et al. Polish 2010 growth references for school-aged children and adolescents. Eur J Pediatr 2011; 170: 599-609. doi: 10.1007/s00431-010-1329-x

4. Świąder-Leśniak A, Kułaga Z, Grajda A, et al. Wartości referencyjne obwodu talii i bioder polskich dzieci i młodzieży w wieku 3-18 lat. Stand Med 2015; 12: 137-150.

5. Kułaga Z, Litwin M, Grajda A et al. Oscillometric blood pressure percentiles for Polish normal-weight school-aged children and sion for Research at the Medical University of Gdańsk (NKBBN/301/2014).

\section{Funding}

Total budget of the programme: 15.481.000 PLN (3.680.956 EUR). The "PoZdro!" programme is financed by Medicover Foundation by a grant from the Jochnick Family Foundation.

The Jochnick Family Foundation had no role in the design of the study and collection, analysis, and interpretation of data and in writing the manuscript.

\section{Acknowledgements}

The authors express their gratitude to all participants, their parents and members of the "PoZdro!" team for their input into the study. The authors would also like to thank the Medicover Foundation administrative staff for their help in conducting the study.

adolescents. J Hypertens 2012; 30: 1942-1954. doi: 10.1097/ HJH.0b013e328356abad

6. Prochaska JO, DiClemente CC, Norcross JC. In search of how people change. Applications to addictive behaviors. Am Psychol 1992; 47: 1102-1114. doi: 10.1037//0003-066x.47.9.1102

7. Jankowski M, Niedzielska A, Brzezinski M, et al. Cardiorespiratory fitness in children: a simple screening test for population studies. Pediatr Cardiol 2015; 36: 27-32. doi: 10.1007/s00246-014-0960-0

8. Reinehr T, Andler W. Changes in the atherogenic risk factor profile according to degree of weight loss. Arch Dis Child 2004; 89 : 419-422. doi: 10.1136/adc.2003.028803

9. Wang Y, Wu Y, Wilson RF, et al. Childhood obesity prevention programs: comparative effectiveness review and meta-analysis (Structured abstract). Database Abstr Rev Eff 2013: 1.

10. Wolfenden L, Nathan NK, Sutherland R, et al. Strategies for enhancing the implementation of school-based policies or practices targeting risk factors for chronic disease. Cochrane Database Syst Rev 2017; 11: CD011677. 